\title{
Mainland China and Hong Kong Closer Economic Partnership Arrangement Effect Analysis
}

\author{
Juan Yang \\ School of Economics, Jinan University, Guangzhou, China \\ Email: 570158333@qq.com \\ Received 30 June 2016; accepted 1 August 2016; published 4 August 2016 \\ Copyright (C) 2016 by author and Scientific Research Publishing Inc. \\ This work is licensed under the Creative Commons Attribution International License (CC BY). \\ http://creativecommons.org/licenses/by/4.0/

(c) (i) Open Access

\begin{abstract}
Based on gravity model, this paper analyzes the impact of Mainland China and Hong Kong Closer Economic Partnership Arrangement by using the data from 2004 to 2013. The result shows that, closer economic partnership arrangement has not promoted the goods export of Hong Kong; the effects on services trade and investment are limited. The main reasons may be the disappearance foundation of the cooperation between the two sides and the limited openness of Mainland China market.
\end{abstract}

Keywords

Effect, Goods, Service, Investment, CEPA

\section{Introduction}

On June 29, 2003, China's first free trade agreement, Mainland China and Hong Kong Closer Economic Partnership Arrangement (CEPA) was signed in Hong Kong. This agreement not only represents the highest level of China's opening to the outside world, but also symbols the cooperation between Mainland China and Hong Kong entering a new historical stage. From 2004 to 2013, Mainland China and Hong Kong signed ten complementary agreements; the field of cooperation continues to deepen and expand. CEPA includes three major aspects-goods, services and investment facilitation. The aspect of goods trading is composed of zero tariff policy and rules of origin. According to CEPA agreement, 273 items products enjoy zero import tariffs since January 1, 2004. And later the implementation of zero import tariff expands to all origin products of Hong Kong. Opening of services industry and liberalization of services trade is the most characteristic and the most important arrangement of CEPA. Until January 1, 2014, the two sides have so far announced 411 liberalization measures in 
50 service sectors, which include banking services, legal services, insurance services, telecommunications services, transportation services, distribution services and so on. Investment facilitation means that both governments promote the cooperation in trade and investment by institutional guarantee. In the early stage, investment facilitation carried out in eight fields: customs clearance, commodity inspection and quarantine, food safety, quality standards, e-commerce, legal transparency, cooperation of small and medium sized enterprises, and industrial cooperation. Later, intellectual property protection, brand cooperation, and trade cooperation are added. Theoretically, CEPA reduces the cost of trade and investment to Mainland China from Hong Kong; it could greatly increase the goods, services, investment of Hong Kong to Mainland China.

By 2013, CEPA has been implemented for ten years. The effect of CEPA on Mainland China and Hong Kong becomes a hot topic, attracting many scholars' attention. Wang Peng (2008) used gravity model to measure the trade potential of Hong Kong and Mainland China. Hua Xiaohong et al. (2008), and Zhang Guangnan (2011) used GTAP model to estimate the effect of CEPA zero tariff policy on Hong Kong. Yu Fei (2009) used gravity model to estimate the effect of CEPA on Hong Kong services trade; the results show that Hong Kong and Guangdong Province benefit a lot from CEPA. The recent work of Zhang Yingwu et al. (2015), has found that the overall effect of CEPA on Hong Kong services export is not obvious, but the effects are different on various industries. These views have very important reference value for our research. This paper differs from above in following respect. Our work about CEPA effect is a comprehensive research, and involves goods, services and investment. Based on the gravity model, we intend to analyze the impact of Mainland China and Hong Kong Closer Economic Partnership Arrangement by using the data from 2004 to 2013.

\section{Model, Variables and Data}

Since 1960s, the gravity model has been widely used in the field of international trade and the evaluation of the effect of FTA, such as Anderson (1979), Clausing (2003), Levy et al. (2003), Adams et al. (2004), Jaumotte (2004), Roberts (2004), Lederman et al. (2005), Tongzon (2005), Medvedev (2006), Jing Men (2007), Baier \& Bergstrand (2007), Chin \& Stubbs (2010), Sheng Yu et al. (2012). Frenkel et al. (2004), Yu et al. (2010), Li Xuan (2011), Wang Jing (2012) use the gravity model to estimate the effect of CAFTA and CEPA on FDI respectively. The basic form of the gravity model is that the trade flow between two countries is directly proportion to the economic scale of the trading country, and is inversely proportional to the distance.

$$
Y_{i j t}=\partial_{0}+\partial_{1} X_{i t}+\partial_{2} X_{j t}+\partial_{3} \text { dist }_{i j}+\xi_{i j t}
$$

where $Y_{i j t}$ denotes the volume of trade or investment of two countries (regions), $X_{i t}$ and $X_{j t}$ denotes economic scale of both sides in year $\mathrm{t}$, generally expressed by GDP, dist $t_{i j}$ denotes the distance between trading countries (regions). This paper based on the traditional model, join the common language, the common boundary and CEPA, as dummy variables. We therefore estimate the extend mode:

$$
Y_{i j t}=\partial_{0}+\partial_{1} G D P_{i t}+\partial_{2} G D P_{j t}+\partial_{3} d i s t_{i j}+\partial_{4} C E P A+\partial_{5} \text { Bor }_{i j}+\partial_{6} \text { Lang }_{i j}+\xi_{i j t}
$$

where $Y_{i j t}$ represent the dollar value of Hong Kong export goods, services or FDI to country (regions) $j$ in year t. $G D P_{i t}$ and $G D P_{j t}$ denotes Hong Kong and its trade partner's economic scale, is expected to be positive as large market size will encourage produce and investment. dist $t_{i j}$ is expected to be negative as it can proxy for both trade or investment costs. CEPA, Bor ${ }_{i j}$, Lang $_{i j}$ are dummy variables. CEPA represents Hong Kong and Mainland China whether signed a free trade agreement, its sign is ambiguous. Bor $r_{i j}$ and Lang $_{i j}$ show whether the countries or regions share a common border or languages, reflect the border and culture effect on the trade and investment, both expected to be positive.

\section{Sample and Data}

CEPA involves goods trade, services trade and investment three aspects, because CEPA has relatively strict rules of origin, only Hong Kong domestic exports benefit zero tariff policy. We select ten major domestic exports, services exports and foreign direct investment exports countries (regions) as observation sample respectively. In 2013, the value of Hong Kong domestic exports, services exports and foreign direct investment exports to these countries (regions), respectively accounting for 77.4 percent, 82.3 percent and 94.5 percent of total domestic export, services export and foreign direct investment export in Hong Kong, have a strong representation. Sample period is 1998-2013. In order to eliminate the multiple co-linearity, take the natural logarithm of data 
beside dummy variables. Some years of Hong Kong FDI export data are less than 0, for ease of take the natural logarithm, all data of the effect of FDI gravity model plus 22.9 (minimum absolute value of negative plus 1) and then take the natural logarithm. Hong Kong major domestic exporters are Mainland China, the United States, Chinese Taipei, Singapore, Vietnam, Macao, India, Australia, South Korea and Malaysia, major services exporters are Mainland China, the United States, France, Germany, Australia, Japan, Korea, Singapore, Chinese Taipei and the United Kingdom, major FDI exporters are Mainland China, British Virgin Islands, the Cayman Islands, Bermuda, British, Australia, Luxembourg, Singapore, Canada and the United States.

The data comes from a variety of source. Hong Kong domestic export, services export and FDI data are collected from the Hong Kong government census and statistic department. The national GDP data comes from IMF Financial Statistical Yearbook. The language and border data are from the distances database of Centre D' Etudes Prospectives et D’Informations Internaionales (CEPII). The distance measured as the distance between Hong Kong and trade or investment partner capitals. Whenever Hong Kong and trade or investment partner use the same language, the language dummy variables assumes a value of 1 ; the variable is zero otherwise. The border dummy variable assumes zero beside Mainland China. Because CEPA formal implemented in 2004, so this dummy variable assumes a value 1 after 2004, assumes a value zero before 2004.

\section{Results}

This paper use stata12.0 to regress the gravity model of CEPA effect of Hong Kong goods export, services export and FDI. In order to modify different variance, sequence correlation and obtain a more efficient estimator, we use generalized least squares (GLS) to estimate the random effects model. Table 1 reports results for the estimation of the effect of CEPA.

\subsection{The Effect of Goods Export}

Estimate 1 and 2 shows the results of the basic gravity model and extend gravity model respectively in Table 1. The coefficient for the trade partner's economic scale, distance, common language and common boundary variables are consistent with the theoretical model, and statistically significant. The effect of common boundary variable is obviously, the contribution rate to Hong Kong domestic export is 207.1 percent $\left(\mathrm{e}^{1.122}-1\right)$. In this paper's sample, only China Guangdong Province shares a common border with Hong Kong. This result illustrates

Table 1. Effect of CPEAE stimation results.

\begin{tabular}{|c|c|c|c|c|c|c|}
\hline \multirow{3}{*}{ Variables } & \multicolumn{6}{|c|}{$\operatorname{InY} Y_{i t}$} \\
\hline & \multicolumn{2}{|c|}{ Goods export effect } & \multicolumn{2}{|c|}{ Services export effect } & \multicolumn{2}{|c|}{ FDI effect } \\
\hline & 1 & 2 & 1 & 2 & 1 & 2 \\
\hline Constant, $\partial_{0}$ & $\begin{array}{c}26.814^{* * *} \\
(13.71)\end{array}$ & $\begin{array}{c}19.553^{* * *} \\
(2.62)\end{array}$ & $\begin{array}{c}-10.590^{* * *} \\
(-15.89)\end{array}$ & $\begin{array}{c}-6.478^{* * *} \\
(-7.94)\end{array}$ & $\begin{array}{c}2.575 \\
(-1.54)\end{array}$ & $\begin{array}{l}-3.916 \\
(-1.33)\end{array}$ \\
\hline 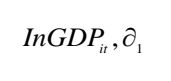 & $\begin{array}{c}-2.189^{* * *} \\
(-13.62)\end{array}$ & $\begin{array}{c}-1.549^{* *} \\
(-2.48)\end{array}$ & $\begin{array}{l}1.434^{* * *} \\
(26.43)\end{array}$ & $\begin{array}{l}0.918^{* * *} \\
(13.73)\end{array}$ & $\begin{array}{c}0.942^{* * *} \\
(6.86)\end{array}$ & $\begin{array}{l}0.537^{* *} \\
(2.21)\end{array}$ \\
\hline $\operatorname{InGDP} P_{j t}, \partial_{2}$ & $\begin{array}{c}0.933^{* * *} \\
(110.50)\end{array}$ & $\begin{array}{c}0.739^{* * *} \\
(9.44)\end{array}$ & $\begin{array}{l}0.572^{* * *} \\
(227.07)\end{array}$ & $\begin{array}{c}0.637^{* * *} \\
(124.85)\end{array}$ & $\begin{array}{c}-0.052^{* * *} \\
(-4.85)\end{array}$ & $\begin{array}{c}-0.067^{* * *} \\
(-5.58)\end{array}$ \\
\hline Indist $_{i j}, \partial_{3}$ & $\begin{array}{c}-0.558^{* * *} \\
(-44.86)\end{array}$ & $\begin{array}{c}-0.379^{* * *} \\
(-3.89)\end{array}$ & $\begin{array}{c}-0.611^{* * *} \\
(-64.34)\end{array}$ & $\begin{array}{c}-0.560^{* * *} \\
(-34.55)\end{array}$ & $\begin{array}{c}-0.521^{* * *} \\
(-12.85)\end{array}$ & $\begin{array}{c}0.128^{* * *} \\
(3.79)\end{array}$ \\
\hline$C E P A, \partial_{4}$ & & $\begin{array}{l}-0.122 \\
(-0.56)\end{array}$ & & $\begin{array}{c}0.206^{* * *} \\
(8.62)\end{array}$ & & $\begin{array}{l}0.196^{* *} \\
(2.24)\end{array}$ \\
\hline$B o r_{i j}, \partial_{5}$ & & $\begin{array}{c}1.122^{* * *} \\
(3.87)\end{array}$ & & $\begin{array}{l}0.328^{* * *} \\
(10.73)\end{array}$ & & $\begin{array}{l}2.252^{* * *} \\
(21.77)\end{array}$ \\
\hline Lang, $\partial_{6}$ & & $\begin{array}{c}0.734^{* * *} \\
(4.00)\end{array}$ & & $\begin{array}{l}1.093^{* * *} \\
(65.80)\end{array}$ & & $\begin{array}{c}0.256^{* * *} \\
(2.83)\end{array}$ \\
\hline Observations & 160 & 160 & 160 & 160 & 160 & 160 \\
\hline
\end{tabular}

Notes: Standard errors in parentheses. ${ }^{* * *},{ }^{* * *}$ denote significant at the $10 \%, 5 \%$, and $1 \%$ level, respectively. 
the importance of China Guangdong Province to Hong Kong in domestic export. The coefficient for economic scale of Hong Kong variable is negative and statistically significant, not consistent with the theoretical model. The reason may be that Hong Kong economy is dominated by service industry, manufacturing in the national economy accounted for less than 5 percent since 2000.GDP cannot accurately measure the supply capacity of domestic products export of Hong Kong.

The coefficient of CEPA is insignificant, it means the implementation of CEPA has no substantial impact on the export of Hong Kong domestic products. 1980s, Hong Kong's manufacturing industry occupied the leading position in the national economy, rapid economic development and resource scarcity led the prices of land, labor, raw materials keep rising. At the same time, Mainland China implemented reform and opening-up policy, attracted by the cheap production factors, a large number of manufacturing enterprises in Hong Kong moved to Mainland China, the local manufacturing industry decline rapidly. Until 2013, Hong Kong manufacturing industry proportion of GDP is only 1.4 percent. According to CEPA regulations, Hong Kong product enterprises must obtain the certificate of origin. As the statistics of Hong Kong industrial and Trade Department, from January 1, 2004 to the end of December 2013, Hong Kong industrial and Trade Department issued 108,524 copies of certificate of origin, the total value of the goods involved is fifty-six billion eight hundred and ten million Hong Kong dollar, only accounted for 16.8 percent of Hong Kong domestic exports to Mainland China. In addition to the above reasons, Mainland China has a wide areas, the effect of CEPA declined with the increase of distance. And strong local protectionism in different provinces of Mainland China, restricted the product, capital, personnel moving. All these reasons limited the overall trade effect of CEPA.

\subsection{The Effect of Services Export}

The coefficient for economic scale, distance, common language and common boundary variables are consistent with the theoretical model, and statistically significant. The effect of common language variable is obviously. Because most of services products cannot be stored, production and consumption simultaneously, the services providers and receivers must participate in trade at the same time, contact and communication with common language and culture background are very important in services trade. The coefficient of CEPA is positive, and statistically significant, it means the implementation of CEPA has promote the export of Hong Kong services, but the effect is limited, only 22.88 percent $\left(\mathrm{e}^{0.206}-1\right)$.

CEPA services trade cooperation between Hong Kong and Mainland China is more effective than goods, which is rooted in the complementarity between the two sides in the field of services trade. Mainland China manufacturing industry highly developed, but services industry relatively backward, and has strong demand for producer services. While Hong Kong economy is supported by service industry, the development level and competitiveness of modern service industry is far higher than Mainland China. As the implement of CEPA, Hong Kong and Mainland China services trade cooperation has get a certain score, but not as expected. The main reason is that the level of economic development and specialized division of Mainland China is low, demand for modern service industry is inadequate, unable to effectively docking with Hong Kong modern service industry. In addition, affected by the low level of development of the industry, Mainland China services market openness is limited, especially the banking, insurance and other important areas are still exist different degrees of monopoly. Although CEPA reduce the requirements of service industry in Hong Kong to enter Mainland China market, but Hong Kong services enterprises are small, the cost for them to entering Mainland China market still high. These reasons lead to CEPA services trade effect is not as expected.

\subsection{The Effect of FDI}

The coefficient of FDI importer economic scale is negative and statistically significant, not consistent with the theoretical mode. But the coefficient is very small, only $0.067 \%$, means the effect to Hong Kong FDI is very limited. The reason may be that the British Virgin Islands, the Cayman Islands, Bermuda attract Hong Kong FDI not because of their economic scale, but they are all famous international tax havens. The other variables are consistent with the theoretical model, and statistically significant. The same with domestic export, the effect of common boundary variable is obviously. Mainland China Guangdong province take advantage of geography, become the most important market of Hong Kong domestic export and FDI in Mainland China. The coefficient of CEPA is positive, and statistically significant, it means the implementation of CEPA has promoted Hong Kong FDI, but the effect is also limited, only21.65\% $\left(\mathrm{e}^{0.196}-1\right)$. 
At present, FDI is often performance as investment in the services industry. As previously analyzed, Mainland China services industry development level is low, the openness of services market is limited and not complete. These reasons restricted the effect of CEPA on FDI, and cause Hong Kong foreign direct investment to Mainland China seriously imbalance in the regions and industries. As Table 2, after the implementation of CEPA, the east regions of Mainland China such as Guangdong, Jiangsu, Zhejiang, Shanghai and other provinces and cities, due to the geopolitical, economic development levels, human resources, infrastructure and other reasons, attracted more than $80 \%$ of foreign direct investment from Hong Kong. The investment of middle region reduced from 14.7 percent to 9.2 percent since 2003. But the proportion of west region increased from $4 \%$ to 9\%.From the industries distribution, Hong Kong investment projects to Mainland China manufacturing and real estate were 5147 and 347, investment amount twenty-four billion three hundred and eighty million US dollars and seventeen billion eight hundred and sixty million US dollars respectively, accounted for $37.2 \%$ and $27.2 \%$ of the total investment to Mainland China of Hong Kong in 2012. Followed by the traditional services industry, wholesale and retail trade accounted for 9.3 percent. Although the rate of investment of scientific research, and technical service, information transfer, software technology service, financial service and other modern service growth fast, but the proportion in total investment is very small, less than $3 \%$.

\section{Conclusions and Policy Recommendations}

\subsection{Conclusions}

This paper used Hong Kong domestic export, services trade and FDI data from 1998-2013, based on gravity model, and analyzed the effect of CEPA. The result shows that the export of Hong Kong domestic, services trade and FDI mostly are direct proportion to economic scale, common language and common boundary, and inversely proportion to the distance between trading partner. The common boundary is the most obviously influencing factor to the export of Hong Kong domestic and FDI. The most obviously influencing factor to the export of Hong Kong services is common language. The effect on Hong Kong domestic export is not obviously. The effect on Hong Kong services trade and FDI is 22.88 percent and 21.65 percent respectively. That means, the complementation of CEPA has not promoted the export of Hong Kong domestic export, and the effect on services trade and FDI is limited. The reasons may be the shrinking of Hong Kong manufacture, limitation of Mainland China market opening, low-level of Mainland China economic development and incomplete market.

\subsection{Policy Recommendations}

In order to promote the cooperation of Mainland China and Hong Kong, give full play of the effect of CEPA, we propose the following suggestions.

Table 2. The regional distribution of investment of Hong Kong to Mainland China.

\begin{tabular}{ccccccc}
\hline \multirow{2}{*}{ Year } & \multicolumn{2}{c}{ East region } & \multicolumn{2}{c}{ Middle region } & \multicolumn{2}{c}{ West region } \\
\cline { 2 - 6 } & Amount & Proportion & Amount & Proportion & Amount & Proportion \\
2003 & 144.0 & 81.4 & 25.9 & 14.7 & 7.0 & 4.0 \\
2004 & 156.5 & 82.4 & 27.4 & 14.4 & 6.0 & 3.2 \\
2005 & 153.2 & 85.4 & 17.5 & 9.8 & 8.7 & 4.9 \\
2006 & 191.3 & 89.8 & 13.9 & 6.5 & 9.9 & 3.7 \\
2007 & 237.5 & 85.7 & 25.7 & 9.3 & 13.8 & 5.0 \\
2008 & 338.9 & 82.6 & 33.9 & 8.3 & 37.6 & 9.2 \\
2009 & 390.2 & 84.7 & 26.2 & 5.7 & 44.4 & 9.6 \\
2010 & 501.1 & 82.7 & 41.3 & 6.8 & 63.3 & 10.5 \\
2011 & 580.5 & 81.3 & 45.0 & 6.3 & 88.6 & 12.4 \\
\hline
\end{tabular}


1) CEPA should continue to expand the commodity list of zero tariff policy, simplified and shorten the origin certification approval procedures, realize the real liberalization of trading in goods.

2) Mainland China should reduce the entering requirement of Hong Kong service enterprises, relax restrictions of services producers, shorten the administrative process of application, improve administrative efficiency, eliminating market barriers, making Guangdong Province as a pilot in the forefront of opening and cooperation, in order to accumulate the experience of service industry cooperation between Mainland China and Hong Kong.

3) Strengthen the industries and regions guidance of investment of Hong Kong. Improve the construction and management of the financial market of Mainland China. Accelerate technological innovation, promote adjustment of industrial structure, lay the foundation for Hong Kong investment entering high-tech industry. Raise the openess of middle and west region, guide the investment of Hong Kong to middle and west region by preferential policies and measures.

This paper focus on the effect of CEPA on Hong Kong domestic export, services trade and FDI, but CEPA is an agreement involved Hong Kong, Mainland China and Macao. To evaluate the effect of CEPA comprehensively and objectively, we must take Mainland China and Macao into account. And these will be the research direction for this paper in the future.

\section{References}

Baier, S. L., \& Bergstrand, J. H. (2007). Do Free Trade Agreements Actually Increase Members’ International Trade? Journal of International Economics, 71, 72-95. http://dx.doi.org/10.1016/j.jinteco.2006.02.005

Chin, G., \& Stubbs, R. (2010). China, Regional Institution-Building and the China-ASEAN Free Trade Area. Review of International Political Economy, 18, 277-298. http://dx.doi.org/10.1080/09692291003762548

Clausing, K. A. (2003). Trade Creation and Trade Diversion in the Canada-United States Free Trade Agreement. Canadian Journal of Economics, 34, 677-696. http://dx.doi.org/10.1111/0008-4085.00094

Frenkel, M. et al. (2004). A Panel Analysis of Bilateral FDI Flows to Emerging Economies. Economic Systems, 28, $281-300$. http://dx.doi.org/10.1016/j.ecosys.2004.01.005

Jing Men 景汶 (2007). The Construction of the China-ASEAN Free Trade Area: A Study of China's Active Involvement 中国与 ASEAN 建设自由贸易区的研究. Global Society, 21, 249-268. http://dx.doi.org/10.1080/13600820701201954

Roberts, B. (2004). A Gravity Study of the Proposed China-ASEAN Free Trade Area. The International Trade Journal, 18, 335-353. http://dx.doi.org/10.1080/08853900490518208

Sheng Yu, Tang Hsiao Chink, \& Xu Xinpeng 圣于, 唐小林, 许新鹏 (2012). The Impact of ACFTA on People’s Republic of China-ASEAN Trade: Estimates Based on an Extended Gravity Model for Component Trade 基于扩展引力模型的 ACFTA 对中国-ASEAN 贸易影响的研究. Working Paper Series on Regional Economic Integration No. 99. http://hdl.handle.net/11540/1302

Tongzon, J. L. (2005). ASEAN-China Free Trade Area: A Bane or Boon for ASEAN Countries? The World Economy, 28, 191-210. http://dx.doi.org/10.1111/j.1467-9701.2005.00643.x

Yu, J., \& Cheng, S. (2010). The ASEAN-China Free Trade Area: Genesis and Implications. Australian Journal of International Affairs, 58, 257-277. 


\section{Submit or recommend next manuscript to SCIRP and we will provide best service for you:}

Accepting pre-submission inquiries through Email, Facebook, LinkedIn, Twitter, etc.

A wide selection of journals (inclusive of 9 subjects, more than 200 journals)

Providing 24-hour high-quality service

User-friendly online submission system

Fair and swift peer-review system

Efficient typesetting and proofreading procedure

Display of the result of downloads and visits, as well as the number of cited articles

Maximum dissemination of your research work

Submit your manuscript at: http://papersubmission.scirp.org/ 